(1) and

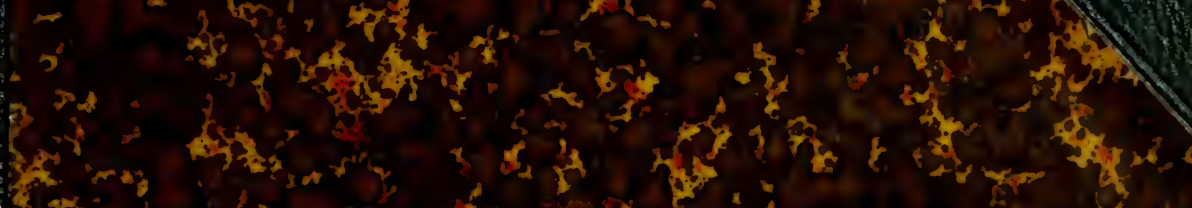

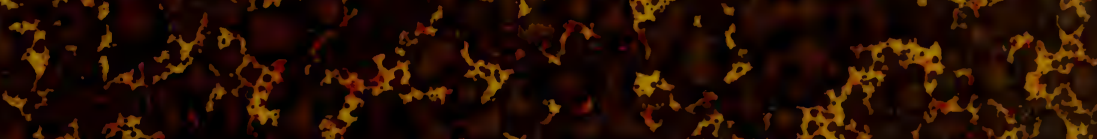
(a) $x y$, on

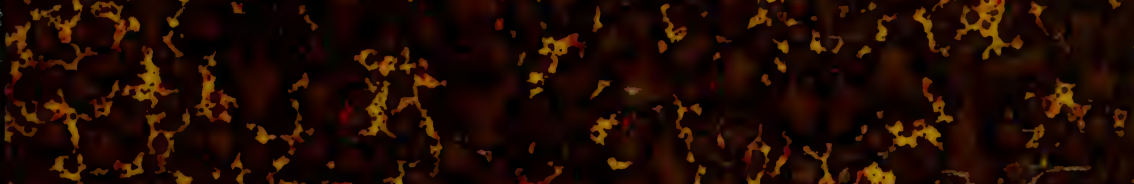

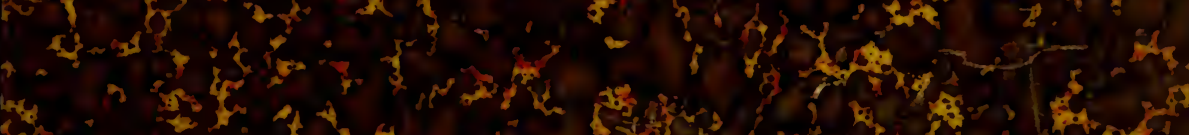
然

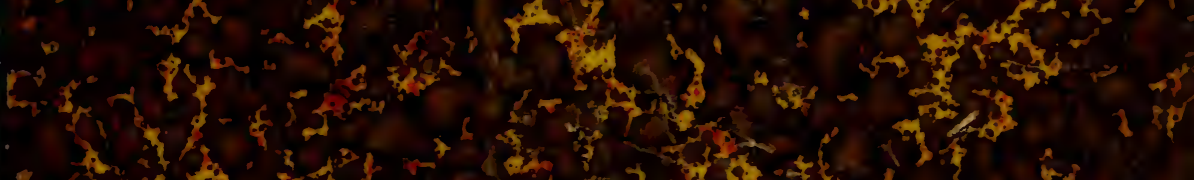

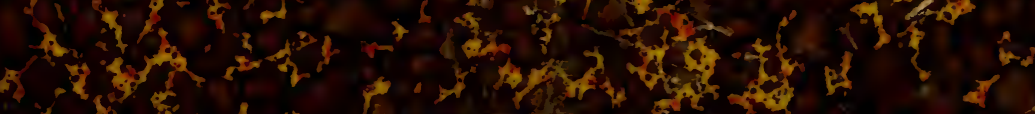

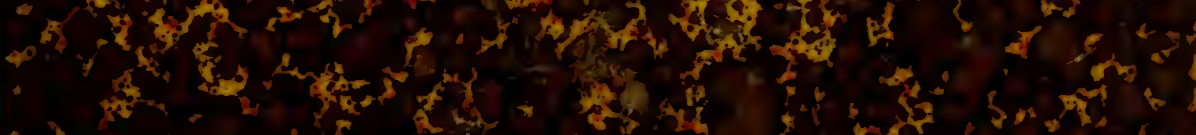

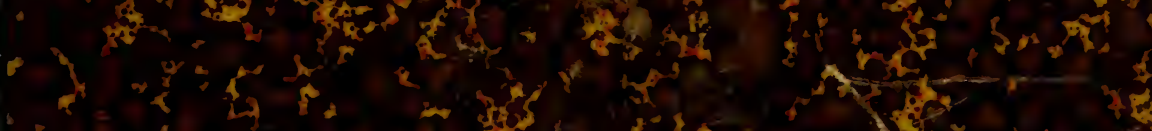

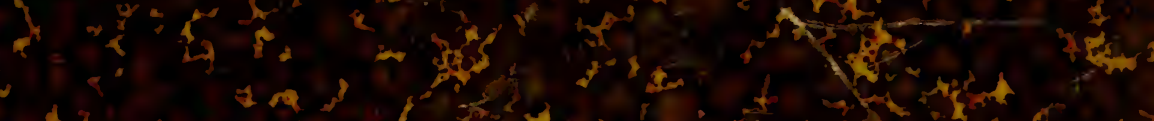

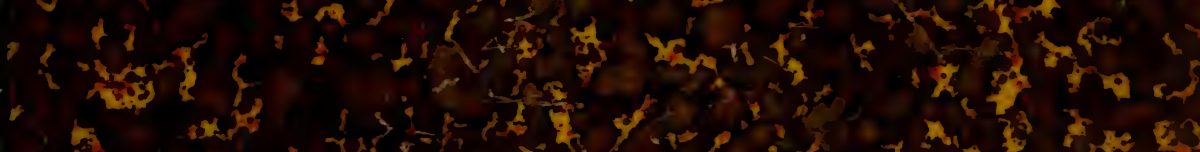

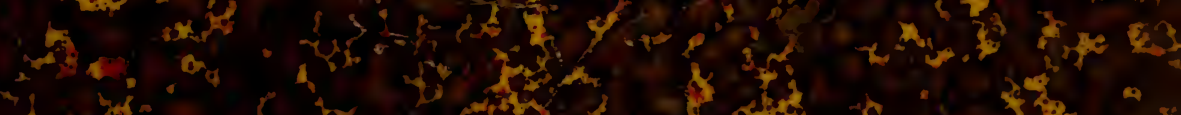

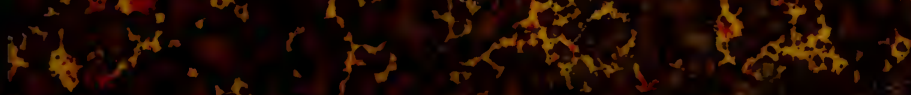

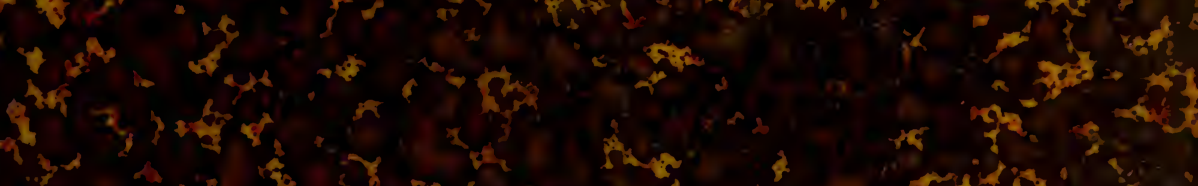

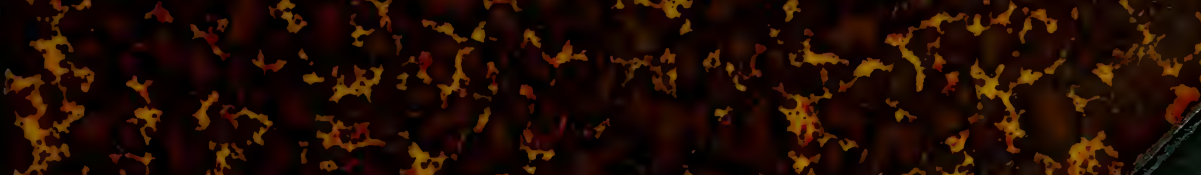

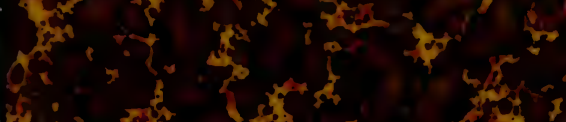

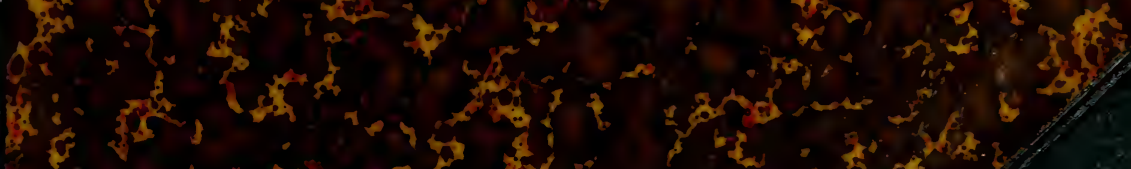

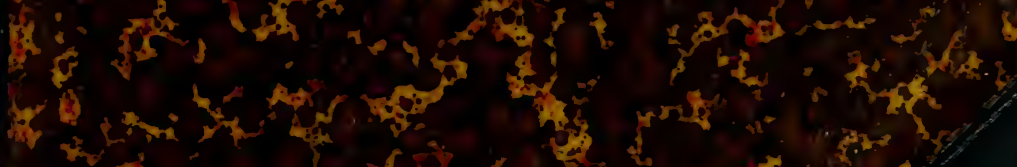

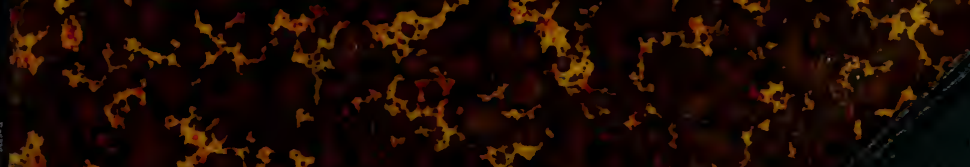




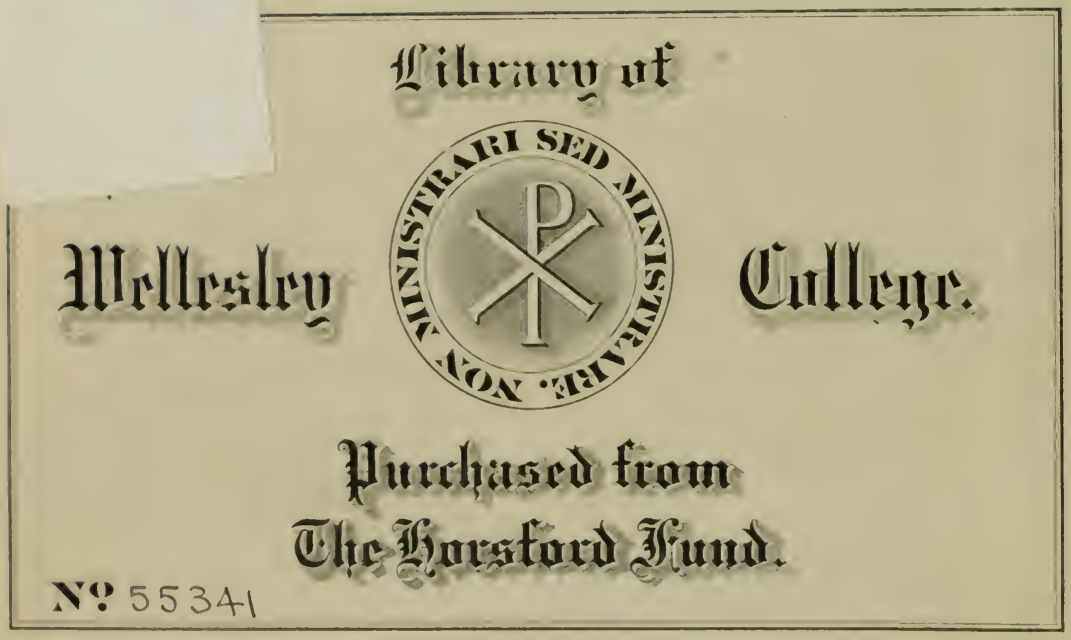





MEMOIRS

OF THE

\section{Torrey Botanical Club}

VOLUME VI

NEW YORK

I 896-I 899 
55341

Sceera

$Q k$
$T 62$
$6-7$ 


\section{CONTENTS.}

No. I.

An Enumeration of the Plants Collected in Bolivia by Miguel Bang.-III. By Henry H. Rusby. (Issued I 896 )

No. 2 .

A Revision of the North American Isotheciaceae and Brachythecia. By Abel Joel Grout. (Issued July 30, I897. I 3 I-2 Io No. 3 .

The Life History of Sphaerella lacustris (Haematococcus pluvialis). Plates 86, 87. By Tracy Elliot Hazen. (Issued May 8, r 899). $211-246$

No. 4 .

A Review of the Genera of Ferns proposed prior to 1832. By Lucien Marcus Underwood. (Issued December I, r 899) $247-283$

No. 5 .

Notes on Lichen Distribution in the Upper Mississippi Valley. By Bruce Fink. (Issued December I, r 899)... 285-306 


\section{MEMOIRS \\ OF THE \\ TORREY BOTANICAL CLUB}

Vol. II

Yo. 3

The Life History of Spharella lacustris (Haematococcus pluvialis)

By Tracy Elliot HazeN

(Plates 86,87 )

Sphacrella lacustris has often been employed in biological textbooks (generally under the name Hacmatococcus or Protococcus pluaialis) as the lowest type of plant life. It is a type which is of particular value for elementary study because of its clear morphological characters and interesting development and also because this development may be regulated with comparative ease for class work.

Unfortunately, however, the treatment of the life history in the text-books is meagre and more or less marred by errors. Furthermore, although numerous memoirs and abstracts on this subject have been published, they are for the most part inaccessible to American students, or (especially in the case of abstracts) are so filled with misconceptions due to insufficient personal observation as to be of little value.

It was with the purpose of clearing up such errors, and of furnishing an account of the life history of this. type that might be available for students, that the present study of Sphacrella was undertaken over two years ago.

In this report the first person has been frequently used because it was believed that the value of the account would be increased by thus clearly separating personal observations from previously published opinions.

I wish to express my gratitude to Professor L. R. Jones, of the 
University of Vermont, and to Professor L. M. Underwood, of Columbia University, for their encouragement and aid in this study; and to the several botanists and zoölogists who have furnished information regarding the distribution of . Sphacrella and especially those who have sent specimens for comparison.

\section{General Account}

Sphacrella lacustris is usually found in urns or shallow pools formed in rock hollows which are either periodically filled with rain or supplied by water oozing from overhanging ledges. In these pools a blood.red crust composed of an infinite multitude of minute spherical cells covers every loose fragment of rock and the sides of the basin. The bottom is usually less densely coated, partly because the motile forms in seeking air and light are left at the edges of the water as it evaporates, and partly because the plants resting on the dirt accumulating at the bottom are more easily washed out by storms than those adhering to the solid rock.

If a portion of the red crust after being scraped off and dried for a short time is placed in a dish of water over night, it will be found in the morning that many of the cells are in process of division. During this process the cell mass, whose inner contents are entirely obscured by the blood-red pigment, increases in size and elongates and the outer layer of the thick cellulose cell-wall ruptures and allows the inner layer to be pushed out in a bladder-like expansion (Fig. 3). This gives space for growth and also facilitates the complete rupture of the membrane. Division proceeds until four, eight, or sixteen daughter-cells are produced. These daughter cells increase somewhat in size by absorption of fluid and usually I have found that they form very delicate celiwalls about themselves before leaving the mother-cell-wall (Fig. 5). Each develops a pair of cilia which may sometimes be seen fifteen or twenty minutes before the time of escape.

In some way a rent is made in the attenuated part of the mother-membrane, or less frequently it becomes softened and the daughter-cell bursting out rapidly swims off, ciliated end foremost. These zooids which are often angular and irregular in shape at first, soon become ovoid in consequence of the pressure from within and the tension of the cilia. The forward movement is ac- 
companied by a constant rotation on the longer axis, from right to left, so that the path described is a spiral. The cellulose investment of the zooid, which was at first indistinct or invisible, soon becomes separated from the colored contents by an accumulation of water and appears as a delicate colorless bounding line (Fig. 6). Sometime later under favorable circumstances this cell-wall becomes still further distended and very delicate strands of protoplasm may be seen radiating from the colored mass to the cellwall (Fig. 7).

Meanwhile a border of yellowish-green chlorophyl has been forming about the zooid replacing the outer part of the haematochrom. After a longer or shorter period of movement the zooids come to rest, usually adhering to some object by their cilia at first ; the radial protoplasmic strands and cilia disappear, but often at the anterior end the sheaths which rigidly supported the bases of cilia remain, connecting the cell-wall with the protoplasmic body (Fig. 8). This quiescent cell may quickly divide again. The process, however, differs slightly from that of the original division as no appreciable distention of the mother-cell-wall occurs (Fig. 9); furthermore, the daughter-cells early develop cilia and move about within the mother cell-wall, often for half an hour or longer before going out; the daughter-cell-walls, also, are more likely to be well developed than those of the first generation. These zooids after breaking out increase in size forming more chlorophyl from the periphery inward like those of the first generation (Fig. IO). They also may arrive at a brief quiescent condition and repeat the process of division by which they were themselves formed (Figs. I I-I 4).

The time elapsing between these divisions is variable; sometimes the second generation is produced on the same morning as the first, but more frequently it appears that. new generations are formed on successive mornings. How long this frequent division may continue has not been determined, but the colony may remain in the motile condition for three or four weeks.

At any point in the cycle, cells may go into a permanent resting stage. In that case, after the cessation of movement and disappearance of the protoplasmic processes (Fig. I6), a new thick cellulose coat is secreted close about the protoplasmic body (Fig. I 7), 
while the distended cell-wall of the zooid gradually softens and decomposes. At the end of a long cycle of generations the cells have only a small central globule of haematochrom, but as the permanent resting stage advances the haematochrom increases from the center toward the periphery, the color passing through shades of golden green and brown (Fig. I 8), until the whole cell is of the blood-red color of the original individual (Fig. I9). Such resting-cells do not develop further-except to increase in size-unless desiccation or freezing takes place.

If these cells are dried or subjected to a low temperature, even for a short time, and then again supplied with water, a new cycle of development begins. This may proceed in just the same way as the former cycle; under certain conditions, however, which have not been fully determined, the red resting-cell may divide into a number $(4,8,16,32)$ of microzooids which, unlike the megazooids, swarm actively within the mother-cell-wall for some time before coming out (Fig. 20). These microzooids shoot through the water in a very erratic manner; their shape is narrowly cylindrical or fusiform (Fig. 2 I), or somewhat ovoid in case their movement is less rapid; they have no visible cell-wall and their period of motility is much shorter than that of the megazooids. Many microzooids soon die, others come to rest, secrete a cellulose investment and probably grow into normal resting cells (Fig. 22).

\section{Habitat and Distribution}

Splacerclla lacustris is reported as very common and widely distributed in Europe, where it is found from Scandinavia to Venice. It seemed quite probable, therefore, that investigation would prove an equally wide distribution in Amcrica, even though Wolle, in his Fresh Water Algae of the United States, was unable to furnish any information as to its occurrence here.

Inquiry among leading botanists and zoölogists has shown that the alga is distributed from Vermont to Texas and from Massachusetts to Nebraska (Professor C. E. Bessey) and probably farther west. All the specimens mentioned below, obtained from widely separated stations and from different types of habitat, I have kept under observation in cultures until there was not the slightest doubt that all were referable to the one species, Sphacella lacustris. 
I first collected this alga at Burlington, Vermont, in hollows of a red sandstone quarry where it had been obtained during several seasons for the use of classes in biology at the University of Vermont. I also found it in similar hollows of limestone ledges in the vicinity. I have made a careful study of these pools and found that in all cases they were small basins filled by rain or water oozing from the ledges above, but so shallow as frequently to be dried up during the summer. Similar but deeper basins side by side with these contained Hydrodictyon and Spirogyra, but no Sphacrclla. The apparent reason was twofold: (I) The deeper pools did not furnish the condition of frequently alternating wetness and dryness which culture experiments show is favorable for prolonged vitality, and (2) If the Splacrella did cover the bottom of these deeper basins as they dry up in the hottest weather, when they are re-filled by a heavy rain the cells would be so deeply buried as to be unable to get sufficient air for development.

Professor G. H. Hudson has sent me Splacerclla material from Plattsburgh, New York, where he collects it in hollows of an abandoned quarry in Chazy limestone and in a pot-hole of the Saranac River; he says "these pools become dry in summer and the stones look as if red paint had been spilled upon them."

Splacrella is rather abundant in rock hollows near streams and about the lake at Ithaca, New York. Material collected there in December by Professor F. A. Waugh divided so rapidly that after two weeks I found all the zooids were of a comparatively small size.

Professor W. L. Bray has sent me material from Austin, Texas, where it is found in a pond which lasts almost all the year, forming part of a creek in winter, and also in creek pools near the Colorado River. Chodat ('97) finds that Hacmatococcus is present though not abundant even in the plankton of Swiss lakes, but he considers that in such cases it has been washed out of the rock basins which form its natural home along the shore.

I have Splacirclla material obtained in cemetery urns in Chicago by Professor C. B. Atwell, and in Baltimore by Mr. H. F. Perkins. Professor E. G. Conklin has also found it in such urns in Delaware, Ohio, Evanston, Ill., and Philadelphia. A note in Dr. Harriet Randolph's “Laboratory Directions in General Biology” suggests that the occurrence of Haematococcus in marble urns may be due 
to the lime in the water. It seems more probable, however, that it is simply because the urns provide the conditions of light, aëration, and evaporation demanded by Sp'acarclla. Further support of this view is found in the fact that Alexander Braun (' $5 \mathrm{I}$ ) records the occurrence of this alga not only in basins of granite and sandstone, but also in holy water urns of iron and in a tin roof-gutter.

Dr. H. M. Richards has obtained Splacrella from dripping rocks above high tide at Nahant, Mass. I have found it in a similar place in New York under an overhanging cliff, where the supply of moisture frequently fails even in winter.

This alga was distributed as Hacmatococcus lacustris (Girod) Rostaf. in the Phycotheca Boreali Americana (no. I I4). The material was collected at Bridgeport, Conn., by Mr. Isaac Holden, who informs me that it "formed a soft coating on the vertical face of rough-hewn stones of the abutment of the dam, where the water percolated through the crevices and trickled down the surface. It was very abundant for several seasons, but has not appeared lately. On sloping and horizontal rocks, which had become dry and exposed to the sun, I have seen it forming a closely adherent thin red film, which could not be removed without difficulty." I have scraped such a red coating from a sloping ledge at Richmond, Vermont, which was washed by a very small spring in summer. At certain times, after an increase in the volume and force of the water, much less of the Splaxerclla was to be seen.

Some years ago the fountain in the college yard at Cambridge, Mass., was green with zooids of Sphacrella for a time in the spring, but Dr. Farlow informs me that last year none could be found.

It will be noticed that in the last three localities conditions were unfavorable for the persistence of an organism which may be so easily swept away by an unusual force of water. We are, therefore, justified in concluding that the small rock basins provide the most secure home for Splacrella.

\section{The resting; Condition}

In the typical resting-cells of Splacerclla which vary from eight to eighty microns in diameter, the only structure visible is the spherical mass of protoplasm closely enveloped in a thick membrane of cel- 
lulose. (Fig. I.) By typical resting-cells are meant the entirely red cells, in which the vital processes are at a minimum; for often non-motile cells are found, in which considerable chlorophyl and pyrenoids and a nuclear area are seen, but these cells represent simply a transition between the motile condition and that of complete rest, or a state of non-motile vegetative propagation.

The nucleus and pyrenoids are, indeed, present in the typical resting-cells, but are hidden by the haematochrom, which, partly in solution in oil drops, and partly in micro-crystalline form (Zopf, '95), penetrates the whole mass of protoplasm. That some chlorophyl also is present, even in the pure red cells, is indicated by the researches of Englemann and Zopf.*

\section{REPRODUCTION}

Reproduction is accomplished in three ways:

I. By the formation of large motile daughter-cells or megazooids.

2. By the formation of non-motile daughter-cells.

3. By the formation of smaller motile-cells or microzooids.

\section{The Foriation of Megazooids: the First Generation}

Alexander Braun (' 5 I) apparently was the first to note that the production of zooids under natural conditions occurs early in the morning. The time varies with the season of the year. In the summer the zooids leave the mother-cell-wall so early that I have found it hard to observe the act even by examining the material before sunrise. In early spring and in autumn division does not often take place in the open air before seven or eight o'clock. This variation is undoubtedly to be explained by the difference in the time of sunrise; but that the escape of the megazooids is due not to the atttainment of a certain intensity of light, but rather to the conditions of temperature is indicated by the fact that megazooids may be produced in absolute darkness. When dry material is placed in water in the morning and kept dark for a few hours, megazooids will be formed in abundance. At a temperature of $22^{\circ}-26^{\circ} \mathrm{C}$. five or six hours is sufficient time, while at $16^{\circ}-20^{\circ}$ six to nine hours may be required.

* See the section on the coloring matters. 
In cloudy weather one is likely to find cases of division at almost any hour of the day if the temperature is favorable. This fact indicates that the light which promotes photosynthesis hinders the resorption of materials in preparation for division.

The time required for the formation of megazooids after the actual beginning of division varies with different conditions of light and temperature. In all cases that I have observed continuously under the microscope, the process has occupied at least an hour, often several hours. But there is good reason to believe that light retards the process of division, even as it is unfavorable to the preparatory process, for in completely darkened cultures I have repeatedly found that nearly all division is completed within an hour after its beginning is observed, while in cultures left in ordinary light dividing cells will be found for several hours.

Alexander Braun (' 5 I) says that even before the beginning of division the red color begins to be replaced by a yellowish-green layer from the periphery inwards, but $I$ have not found this to be the fact except when division is delayed, and in case of cells which have not gained the entirely red color of typical resting-cells. When division is accomplished promptly red cells produce red zooids.

After the first cleavage which is transverse, the division follows no constant rule; the second cleavage, though in a plane perpendicular to the first, may begin at both poles simultancously or division may be completed in one hemisphere before it begins in the other. Often when four daughter-portions appear to be completely formed they divide again so as to form eight zooids, but more frequently when eight or sixteen zooids are to be produced the division is so irregular that it cannot be followed easily, or the mass may even appear to break up all at once into numerous daughtercells.

Dangeard ('88) suggests as an explanation for such cases that possibly the resting cells contain several nuclei, and he also thinks that when more than four daughter-cells are formed, the reason may be that the mother-cells have been for some cause prevented from dividing at the normal point and have continued to increase in size. 'This explanation does not appear to me quite sufficient, for not infrequently eight or sixteen zooids are produced by cells no larger than those which produce four or eight. 
I have been unable to find a record of the production of more than eight megazooids in one cell and it has even been stated in some of the text-books that when more than four daughter-cells are produced they are to be regarded as microzooids. Nevertheless I have frequently found in one cell-wall sixteen typical megazooids, each possessing a distinct cell-wall and in point of size equaling and sometimes surpassing the individuals produced in groups of four and eight (Fig. 23). Division often begins before there is any appreciable increase in the size of the cell-mass (Fig. 2), but very soon so much fluid is taken in by endosmosis that the cell-wall is distended until its outer layer is ruptured or softened and an inner layer is pushed out, doubling the original space (Fig. 46). That the amount of distention is not dependent on the amount of increase in the size of the daughter-cells is indicated by the fact that often much more space is formed than they can fill (Fig. 5). Probably this distention is of service also in rendering the membrane thin enough so that it can be ruptured easily when the zosids escape. Generally, however, this part of the cell-wall remains considerably rigid, for when, as sometimes happens, only a small slit is made for the escape of the zooids they are unable to stretch it, but are themselves compressed into a dumb-bell shape in squeezing out (Fig. 34).

It is said by both Cohn and Braun that the daughter-cells possess no cell-wall at the time of escape from the mother membrane. Parker ('93) states that the cell-walls and cilia of megazooids are formed sometimes before, sometimes after they leave the mother-cell-wall. In a great number of cases of division into four, eight and sixteen daughter-cells, the cell-walls have been distinguishable at the moment of escape, if not some time before; in other cases only the deceptive line of color refraction can be distinguished outside the boundary of the protoplasmic mass, but so delicate a structure might easily escape observation under ordinary objectives. As for the cilia it is difficult to imagine how the zooids could swim away from the mother-cell-wall if they were not formed before the escape. 
The Foriation of Megazooids : the latek Generations

The second generation is normally produced after the zooid has passed through a very short quiescent stage, which is by no means equivalent to the regular resting stage since no thick cell-wall is formed.

Most frequently in all generations of megazooids after the first, I have found only two daughter-cells produced, but on two occasions I found that nearly all the megazooids of the second generation were produced in fours (Figs. 9, 52). Braun (' $5 \mathrm{I}$ ) says this is the usual number and that more rarely two or eight are formed.

It is almost impossible in the later stages unless they are produced in drop cultures, to say certainly whether zooids belong to the second or a later generation, for the process of formation is similar in all cases after the first generation.

Braun (' 5 I) states that in the later generations division often begins before the zooid comes to rest. I once found such a case where the mother-cell was swimming rapidly by means of its cilia which were still attached to one of the daughter-zooids, although each of these was moving independently by means of its own cilia (Fig. 38). Perty ('52) says that the cilia of the mother-cell continue to move until the protoplasm breaks up into the daughtercells, and Cohn (' 50 ) states that the movement may continue even after the cilia are detached from the daughter-cells; but in cases where I have seen these detached cilia remaining they have been quite rigid (Fig. 37), and the movement of the cell-wall was caused simply by the motion of the daughter-zooids within.

Perty ('52) has described a figure which he says represents division of a motile cell where the anterior part of the cell-wall is divided by constriction into two beaks, each of which possesses a pair of cilia, while the posterior part is still entire. This, however, must be considered a monstrosity, for normally only the protoplasmic part of a zooid is affected by division.

\section{Vegetative Division}

At the time of his first publication on Protococcus, Cohn (' 50 ) undoubtedly thought that the production of non-motile cells from resting cells formed a regular part of the cycle of development; he indicates that the contents of the resting-cell divide into two 
parts, each of which becomes invested with a cellulose wall; each of these daughter-cells in turn forms two cells, all four become clothed with cell-walls and remain enclosed in the enlarged membrane of the original cell; each of these four cells may divide again to produce a third generation of daughter-cells which may become motile. In a later supplementary description, Cohn (' 54) illustrates the development of Chlamydococcus by figures showing the formation of the zooids in a manner esssentially like that which I have observed (Figs. 2-5,46-48), that is by successive divisions without the formation of cell-walls in the intermediate stages.

Later still Cohn * said there was need of further proof of the development of resting-cells directly from resting-cells (Sclbsttheilung) which he had first described.

Braun (' 5 I ) asserted that a vegetative division does take place, but not as a part of the regular cycle of development previously described. He found that where the cells are kept simply moist and exposed to the air, as is the case under natural conditions, especially in the milder intervals of winter and on the moist edges of rock basins at other seasons, the cells multiply either by simple division or by double halving, but the daughter-cells thus formed do not slip out of the mother-cell-wall; they gradually acquire thick, close cell-walls, while the mother cell-wall expands and disappears. By the frequent repetition of such a process masses of cells become pressed together so that thick crusts of cells bounded by flat surfaces may be formed. This vegetative division is very rarely found in cultures in the laboratory, because of the difficulty of producing artificially the conditions which foster it.

Cohn ('50) notes that temperature is one of the factors which determine whether resting or motile cells shall be produced. On one occasion I found in a glass jar kept on a window ledge a large number of red cells which had developed daughter-cells indistinguishable from ordinary zooids in form. None of them, however, became motile (Fig. 49) and the only possible explanation was that after division had begun a sudden drop in the temperature prevented the daughter-cells from becoming zooids.

I have frequently examined the Sphacrella growing on a moist

* Cohn and Wichura. Ueber Stephanosphaera pluvialis. Ncv. Act. Acad. Caes.

261: Nachtrag. 23. 1857 . 
rock during the present winter. Sometimes I have found large, scattered cells, at other times numerous clusters of small cells clearly indicating recent division, but never any zooids, even though at times there was sufficient water for movement. The reason here again appeared to be that the more abundant water supply was accompanied by so low a temperature that the motile state was not acquired. Material collected from the rock at such times and placed in a slightly warmer atmosphere produced abundant zooids (Figs. 23, 45-48).

Rostafinski ('75), indeed, reports that when he placed vessels containing many zoöspores outside a window at a temperature between $6^{\circ}$ and $2^{\circ}$ multiplication and production of zoöspores continued in normal fashion; when during the night the temperature fell and a mass of purple ice was formed, he found after slow thawing, a large number of zoöspores which showed active vibratory movements. I have repeatedly attempted to confirm these results but I have never been able to discover zooids produced at a temperature lower than $\mathrm{I} 2^{\circ}-\mathrm{I} 5^{\circ} \mathrm{C}$. I have always found that if a vessel containing zooids is slowly frozen the zooids may still continue to live under a crust of ice where the temperature of the water is about $\mathrm{I}^{\circ} \mathrm{C}$., but when actually imprisoned in ice they invariably die. Cohn (' 50 ) also found that motile cells were killed by freczing. It is quite possible that Rostafinski thawed his cultures so slowly that new zooids were formed.

I have never found any evidence of any other type of vegetative propagation than the endogenous division already described. Cohn's figure I 5 which has been copied by Bennett and Murray and others as the palmella-condition of Protococcus may be interpreted as a case of endogenous division in which the daughter-cells have been pressed together so as to be bounded partially by flat surfaces, while the mother-cell-wall has disappeared.

It is to be concluded then, that vegetative division plays an important part in the multiplication of Splucerclla lacustris, but that the process does not differ from that by which zooids are produced except that the motile condition is not acquired because of insufficient water, aëration, or temperature. 


\section{The Formation of Microzoolds}

Alexander Braun ('5I) was apparently the first to distinguish accurately the microzooids from megazooids. He found that during the latter stages of the cycle of generations many cells, instead of producing only four daughter-cells, continued to divide so as to produce a mulberry-like mass which was finally broken up into sixteen or thirty-two minute cells. These "microgonidia" then began swarming actively within the mother-cell-wall and finally burst out; they were of longer shape than the large swarmers, only about 6.6 microns long, of yellowish green color with reddish ciliated points; they did not increase in size or acquire a perceptible membrane but most of them died after coming to rest ; others turned into little red globules whose further development was uncertain. My own observations as to the character and manner of formation of the microzooids agree with Braun's account. Sometimes a zooid which has recently come to rest appears to be forming four megazooids but further watching discloses eight or sixteen active microzooids (Figs. 24, 25). I have, however, found microzooids developed most abundantly from red resting-cells which before being dried had been subject to unfarorable conditions (Fig. 20). The shape of microzooids varies from fusiform or cylindrical when they are most active to ovoid when they are more sluggish. Their rate of movement, nearly always more rapid than that of megazooids, is perhaps to be explained by the fact that their cilia are as long as those of megazooids while their bodies are much smaller. The color varies with that of the mother-cells from which they are produced, but usually when considerable of the yellowish green color is present the red pigment does not form a central mass as in megazooids but is collected at the anterior end (Fig. 28) or in a central girdle (Fig. 26). The movement of one brood of microzooids appears never to continue longer than through one day, though a new brood may be produced from other resting-cells in the same vessel on successive days for a week. Generally most of the microzooids die but sometimes after coming to rest they acquire a thick cell-wall and gradually increase in size as they grow red. I have been unable to develop them further.

By supplying nutriment to these red globules in Van Tieghem cells, Rostafinski (' 75 ) succeeded in causing them to increase to. 
the size of the ordinary resting condition, and then by transferring them to pure water obtained megazooids through the ordinary mode of division. Rostafinski discovered no conjugation and concluded that Haematococcus is an asexual plant. I have frequently found forms presenting the appearance of two microzooids fused at their anterior ciliated ends but no actual meeting has been observed and such forms may be explained as monstrosities resulting from incomplete division.

From the conditions of their formation, however, it seems to me that the microzooids must be potentially gametes. Their formation does not appear to depend entirely on the conditions which affect the water at the time the microzooids are produced, for megazooids may be produced in the same cultures at the same time. On the contrary, when, from lack of nourishment or of a sufficient temperature, the resting-cells are unable to grow to the usual size and strength, microzooids are produced much more abundantly. I have found particularly that when cultures containing Sphaerella are allowed to evaporate more rapidly than under natural conditions, the resting-cells collected on the sides of the vessel, if again supplied with water, nearly always produce microzooids in countless numbers. I have also obtained only microzooids from certain material collected (in Burlington) on rocks where it had been frozen most of the winter, but which, at milder intervals, had probably been able to produce small resting-cells. Material collected from the same place in May and June produced megazooids.

In addition to previous conditions of growth, at the time of division light seems to be favorable for the formation of microzooids. Sachs states that when a certain light intensity is reached swarmspores will break forth. I have rarely been able to produce microzooids in cultures kept dark, as I have megazooids, but the same material, when subjected to a preparatory darkness over night and allowed to receive the natural gradual increase of light in the morning, produces abundant microzooids. On one occasion I found a recently motile cell in which division was beginning at nine o'clock in the evening; I kept it under observation for two hours, during which sixteen micro-daughter-cells were formed; but they did not become motile, perhaps because the light (from an ordinary student-lamp) was not sufficiently intense. 
Since, therefore, microzooids of Sphacrella are formed under the conditions which Klebs found were necessary for the production of the sexual cells in the closely related genus Chlamydomonas, viz., lack of nutriment and presence of light, the assumption that they are potentially gametes appears to be justifiable. If no conjugation really takes place, its absence may be accounted for by the fact that in the successive conditions of activity, slow growth, and rest, a sufficient opportunity for rejuvenescence is found.

\section{The so-Called Coxjugation of Megazooids}

Velten ('7 I) has described and illustrated with considerable detail a process which he considered conjugation of megazooids. This does not differ essentially from cases which I have frequently observed. Two zooids are found attached together by their posterior ends (Fig. 42) and the content of one cell passes over into the other (Fig. 43), the cilia of each cell meanwhile keeping up active movement, at least for a part of the time. Finally a spherical zygote is produced which does not differ from the ordinary resting-cell (Fig. 44), the fate of which Velten did not learn. I have not been able to get any further development from such a product of fusion by cultivating it in a Van Tieghem cell.

Rostafinski (' 75 ) rejects Velten's interpretation of this phe- . nomenon on the ground that it is contrary to all previous observations, in that not microzoöspores, but megazwöspores conjugate, and by their posterior ends instead of by the ciliated points. So far Rostafinski's objection holds good; but when he goes on to say that Velten's conjugation is to be interpreted as a case of a parasitic monad swallowing a zoöspore of Chlamydococcus, I think he is entirely wrong, for the cases (cf. Figs. 39-44) I have observed admit of no such explanation. On the contrary, I think they are cases in which the original division was incomplete and the two-headed monster, after struggling in vain to complete the separation, fuses again to form one cell. This interpretation receives support from one case where I observed the actual formation of such a monstrosity. When the division had reached a stage similar to that shown in Fig. 47, the mother-cell-wall burst and one perfect zooid escaped while the rest of the cell-content issued forth in the form of a large ciliated mass with a smaller 
one attached, each part being invested with a cellulose membrane. Probably the premature rupture in this case was due to the pressure of the cover-glass; the double zooid, however, was vigorous enough to swim about actively after more water was supplied. Very frequently dumb-bell shaped pairs are found which are ciliated at both ends (Fig. 4C) and which do not fuse but sometimes do succeed in becoming separate. More rarely three- or four-headed monstrosities of a similar nature are found (Fig. 4I).

Velten said that these conjugating pairs were always to be found in glass vessels placed in sunlight. I have found these malformations more abundant under such conditions, but sometimes. also even in darkened cultures.

\section{The Alleged. Amoeboid Condtion}

White ('So) has described what he thought might be the transformation of Splacerella (Protococcus pluvialis) into an amoeboid condition. He found amoeboid organisms containing in the center a colored mass like that of Splacerella, and he supposed that "the structureless envelope becomes the homogeneous part of the Amocba while the granular center becomes the granular Amocba." He says further, "I have to-day seen an Amocba with a well-defined homogeneous circular zone having within it a pale green area with the red oil spot but to one side rather than centrally situated, evidently a Protococcus undergoing change to an Amocba. Now the well-defined circle has broken up into the usual amoeboid projections and it has passed beneath some decayed vegetation and become invisible."

Dangeard ('88) discredits this amoeboid state, and there can be little doubt that it represents the case of an Amocba digesting a zooid of Sphacrella. I have several times found such cases. I once observed a rhizopod (Actinoplery's) devour eight megazooids in a short time; the green pigment was quickly digested, the red more slowly.

Special Morphology of Megazooids.-The Cell-iVall axd Sheaths of Cilia

The cellulose character of the cell-wall was doubted by Busk ('53). Cohn ('52), however, states positively that he succeeded in 
demonstrating the cellulose charectər of the cell-wa:l, particularly in the case of the motile cells. The test is not always convincing, but by using rather strong sulphuric acid followed after a few minutes with dilute iodin according to Cohn's directions, I have obtained a blue color which could leave no doubt in one's mind. Although the test is less satisfactory with the resting-cells, probably because they are somewhat coated with a gelatinous substance, yet even here the cellulose reaction is unmistakable.

The sheaths which surround the bases of the cilia (Figs. I 5, I6) usually disappear in the distortion produced by the action of sulphuric acid, but there can be little doubt of the truth of the statement by Kerner* that they consist of cellulose, for they do not take up protoplasmic stains.

\section{The Radial Strayds of Protoplasi}

The use of iodin or other proper stains demonstrates very clearly the protoplasmic character of the threads which radiate from the central colored mass. These threads often appear to end in a slight enlargement without coming into connection with the cellulose wall, but more careful examination often shows that they are finely branched at the end (Fig. I 5) and probably these branches anastomose to form an exceedingly fine network close to the cellwall. This structure is so delicate, however, that I have been unable to demonstrate it by staining or plasmolysis.

The protoplasmic strands are not always visible, even in mature zooids. Zachariast intimates that zooids showing this structure are generally found in the stagnant water of old cultures, and suggests that they exhibit a strong approach to Amocba-like organisms. I have found, however, that even young zooids in fresh cultures when kept in sunlight, show the threads well developed, so that it appears to be a condition accompanying vigorous assimilation and growth.

\section{The Chromatophore and Pyrexoids}

Cohn (' 50 ), considering the colored protoplasmic mass homologous with the "primordial utricle" of plant cells, applied to it the

* Kerner-Oliver. Natural History of Plants, $2: 630 . \quad$ I 895

$\dagger$ O. Zacharias. Experimentelle Untersuchungen über Pseudopodien-Bildung. Biol. Centralb. $5: 26$ I. I 885 . 
name " primordial cell." Taking into account the radial strands of protoplasm and the network which they probably form, this term is hardly suitable. The protoplasmic mass must be regarded as the single chromatophore (Vines, '86, Bütschli, '84). This chromatophore, at first solid, may in the later stages become vacuolated so as to present the form of a hollow green sphere inclosing the red nuclear globule (Fig. 30). Frequently the chlorophyl of this hollow shell becomes reduced in places so that it appears to be pierced with holes (Fig. I 5). It is such conditions which have given rise to the statement that the zooids contain several chromatophores.

The extent to which the haematochrom is changed into chlorophyl appears to depend on the conditions which ordinarily affect the production of chlorophyl. The zooids do not need the haematochrom but much of it may be retained for a day or two if the temperature is not favorable for the formation of chlorophyl. Light is apparently not so essential a factor as warmth, for zooids kept in the dark may develop considerable chlorophyl. Under such circumstances it is noticeable that the haematochrom is more scattered and mixed with the chlorophyl, but when these zooids are brought into the light the haematochrom soon becomes collected into a central globule.

When the conditions are favorable for the formation of chlorophyl the haematochrom may disappear altogether in the later stages (Fig. 32) ; it never seems to have the character of the red " eye-spot" of other genera, but gradually fades out.

In the green chromatophore are embedded several (4-8) pyrenoids. These were called Chloropliyllbläschen by Cohn ('50), who expressed doubt as to the presence of starch in this alga. Braun (' $5 \mathrm{I}$ ) recognized their true nature in relation to starch formation. Frequently the presence of starch cannot be demonstrated by application of iodin, but the test is successful if the culture has been furnished with sufficient light and aëration. The pyrenoids are especially prominent after freezing; they then show a clear nuclear spot in the center. 


\section{A Contractile Vacuole not present}

The presence of a contractile vacuole in this organism is alleged by Cienkorski* and Bennett and Murray ('89). They are, however, undoubtedly in error on this point, for nothing of the kind has been recorded by the men who have become thoroughly acquainted with Sphxerella; in fact, the existence of a contractile organ is expressly denied by Cohn (' 54 ).

There is also one of Bütschli's figures $(P l .43 . f . g a)$ representing a contractile vacuole in Hacmatococcus lacustris-a figure which has been copied by Hansgirg ('88) as Sphaerella lacustris, by Parker ('93) as Hacmatococcus lacustris, $\dagger$ and by Lankester as Haematococcus pahistris! in the article Protozoa in the Encyclopaedia Brittanica. The figure which has caused all this confusion was copied by Bütschli from Stein's figure (Pl. I5. f. 58) of Chlamydococcus fluviatilis Stein, and was never intended to represent the species to which Bütschli applied it. It appears to me, indeed, that Stein's figure does not even represent a Chlamydococcus (Sphaerella) for it has the red eye-spot, contractile vacuole, prominent nucleus + and single large pyrenoid which are characteristic of Chlamydomonas, and in its development also, Stein's species is like this genus rather than like Sphaerella; it corresponds very closely to the Chlamydomonas rostrata described by Cienkowski in the article above referred to, a form which I have collected several times near New York.

\section{The Coloring Matters}

Cohn (' 50) first described the pigment of the resting-cells as a scarlet red oil, soluble in alcohol and ether, and turned blue by iodin. Some years later Cohn ('67) gave to this pigment the name haemato-

* L. Cienkowski. Ueber einige chlorophyllhaltige Gloeocapsen. Bot. Zeit. 23 : 25-27. I 865 .

+ Parker was evidently unaware that Huematococcus lacustris and $H$. pluvialis are synonyms, for he remarks that a contractile vacuole, though absent in $H$. pluvialis, is present in H. lacustris. This confusion might have been aroided had he noticed the footnote in which Bütschli accepts Cohn's objection to the name H. lacustris and readopts $H$. plurialis.

$\mp$ The nucleus is never distinguishable in living zooids of Sphaerella and it is even difficult to demonstrate it by simple staining processes. I have met with success by using osmic acid and carmine as suggested by McNab. Ann. and Mag. Nat. Hist. I2 : 1 24. $188_{3}$. 
chrom and further defined it as a substance different from the coloring matter of the red algae (which is soluble in water) and the purple pigmẹnt found in many Oscillatoriaceae. He inferred that haematochrom is a substance very closely related to chlorophyl since at certain times it appears to be built up directly into chlorophyl; he also supposed that the coloring matter found in Trentepolulia and the red "eye-spots" of zoöspores was haematochrom.

Rostafinski ('S I)* declared that Haematococcus in the snowfields of the Alps never grows green, but the green appearance sometimes ascribed to it is due to a species of Chlamydomonas; since, however, the red cells increase rapidly, he thought it was clear that their plasma could assimilate without chlorophyl and without organic matter in solution. Rostafinski, furthermore, extracted the red pigment (apparently from Trentepollia) and finding that it had a spectrum similar to that of chlorophyl and also became green when exposed to light, he concluded that it was a reduced chlorophyl, and in order to indicate this relationship suggested for it the name chlororufin.

During the next year Engelmann ('S2) made careful investigations to confirm or overthrow Rostafinski's assumptions. By means of his bacterial method $\dagger$ he proved that the pure red cells are able to decompose carbon dioxid under the influence of light, but the reaction was stronger in the greener cells. Next, by research in the microspectrum, Engelmann found that even in the case of the red cells the rays most effective in photosynthesis are those which his previous experiments+ had shown to be the most effective in the case of green cells, viz., the red rays between $B$ and $C$. Finally he found that the pure red cells gave a strong continuous absorption from the yellow to the violet end of the

* It should be noted that Rostafinski considered the "red snow" species Splacerella nivalis (Bauer) Sommerf. identical with his Huematococcus lacustris

$\dagger$ A drop of water filled with red cells of Haematococcus was mixed with a drop containing many active bacteria and mounted under a cover-g' ass and sealed with vaseline. When placed in the light, after a few minutes most of the red cells were surrounded by swarms of bacteria eagerly seeking the oxygen given off by the cells through the decomposition of $\mathrm{CO}_{2}$ under the influence of light acting on the coloring matter. In the dark the movement quickly stopped.

$\ddagger$ T. W. Engelmann. Über Sauerstoffauscheidung von Pflanzenzellen im Mikrospectrum. Bot. Zeit. 40: 417-426. I8S2. (See Vines, I'hysio'ogy of Plants, 225257. I 886 .) 
spectrum, and only a feeble darkening in the position of the characteristic chlorophyl band between $B$ and $C$; while the more the cells changed from red to green, the stronger was the absorption between $B$ and $C$, and the feebler that in the yellow and green. Engelmann's experiments therefore quite justified his conclusion that the photosynthesis in the red cells of Hacmatococcus is due not to the red color but to the presence of chlorophyl mixed with it.

The experiments of. Engelmann with living cells have been confirmed by Zopf's researches on the extracted coloring matters. Zopf ('95) collected about a kilo of red Hacmatococcus and extracted the coloring substances with warm absolute alcohol. From this alcoholic solution he separated* a chlorophyl solution, a yellow pigment solution, and a red pigment solution. Zopf also extracted the so-called haematochrom of Trentcpollia but found that it formed a yellow solution similar to the yellow solution from Haematococcus if not identical with it. This yellow pigment, or carotin, is to be sharply distinguished from the red pigment; it constitutes only a small element in the coloring matters of the red cells of Sphacrella. The red pigment forms a brick- to bloodred colored combination with alkalies and alkaline earths; the solution in alcohol, ether, and petroleum-ether, as well as the evaporation residue, shows the same red tint; and the spectrum gives a single but broad absorption band in the green and blue, strongest in the line $F$. The yellow carotin of Trentepolitia, on the other hand, forms no combination with alkalies and alkaline earths; the extracts in alcohol, ether, and petroleum-ether as well as the evaporation residue are yellow; and the spectrum shows two narrow absorption bands in the blue and indigo.

Zopf thus shows that the assumption by Cohn (' 67 ) and Rostafinski ('8 I) that the reddish pigment of Trentcpohlia and the haematochrom of Hacmatococcus are identical was not warranted by facts. He considers the yellow carotin one of the eucarotins, pigments which are carbohydrates: the red pigment, for which the name haemotochrom may still be used in the restricted sense, is a repre-

* The raw alcoholic mixture was treated with a so'ution of caustic soda and the chlorophyl formed a combination with sodium the yellow pigment became free and the red combined with sodium. A separation was then effected by taking advantage of the fact that the chlorophyl-sodium is solub'e in water, the yellow pigment easily soluble in petroleum-ether and the red less soluble in petro'eum-ether. 
sentative of the carotinins, a class of pigments which show much greater stability; the carotin of Trentcpolnlia keeps its color in the dried state for only two months at the longest, while the haematochrom retains its color for years.

It appears to me not unreasonable to conclude that in its chemical nature haematochrom is closely allied to chlorophyl in spite of the fact that it gives the starch reaction with iodine.

\section{Function of the Hanmatochrom}

When we consider what the value of haematochrom may be to Sphaerella we come to a very perplexing problem. Haematochrom is especially an accompaniment of diminished vitality, and it is, therefore, mainly in connection with the resting stage that we must study its function. Nevertheless, the red color of Sphacrella must have a greater significance, it seems to me, than that found in the winter spores of other fresh-water algae, since it forms so much more constant and permanent a feature.

It has been very generally supposed that red coloring matters have some relation to light. MacDougal* thinks the red color substance of Haematococcus is a protection against the disintegrating effect of light on chlorophyl and protoplasm. That it may serve such a purpose in the pure red cells is quite probable, especially as I have nearly always found only such cells in the pools which are exposed to the glaring sun, even though they were filled with water, while on the rock in New York, scantily supplied with water but turned away from the sun, I have generally found many green celis.

In the partly green cells, as Engelmann has remarked, the red color can have little effect as a protective screen, since it occupies a central position in the cell, and the supposed disintegrating rays which it absorbs, viz., those from the green to the violet end of the spectrum, must pass through most of the chlorophyl and protoplasm before they are acted on by the red pigment.

The researches of Kny and of Kerner show that red coloring matters probably play an important rôle in converting light rays into heat. It is entirely possible that the haematochrom serves this pur$\mathbf{1} 898$.

* J. C. Arthur and D. T. NacDougal. Living Plants and their Properties, 185 . 
pose poth in the greener and in the pure red cells. In the case of the red cells of Sphacrella mialis* especially it appears that such a function would be of great value, since the heat created would be available in melting the snow. Moreover, I have been struck with the fact that, in cultures kept under precisely the same conditions in the laboratory, material from milder climates, e.g. from New York and Baltimore, habitually develops more chlorophyl than material collected in places which are frozen a large part of the winter, as at Burlington, Vermont, and Plattsburgh, New York.

From the fact that the haematochrom is wrapped about the nucleus, and except in rare cases (Fig. 33) envelops each daughternucleus during the process of division, it might be suspected that it has some food value.

The key to its most important function, however, may lie in the chemical nature of the haematochrom. It possesses much greater stability than chlorophyl and therefore probably plays an important part in enabling the cells to endure adverse circumstances. I have found that zooids furnished with considerable haematochrom are less quickly destroyed by sudden changes of light and temperature than greener ones.

\section{IRRITABILITY OF ZOOIDS}

The zooids of Sphacrlla furnish very interesting material for studies in sensitiveness. In general they are strongly attracted toward light so that, when they are cultivated in glass vessels, the margin of the water nearest the light will be colored red or green by the accumulation of zooids in that part, while very few will be found in other parts of the vessel.

This light-seeking tendency, however, varies somewhat with circumstances. Strasburger (' 78 ) found that the young zooids would swim towards a light from which they would move away when older, and that though zooids sought the light at a temperature of $16^{\circ}-18^{\circ}$, they shunned light of the same intensity at $4^{\circ}$. I have found, on the contrary, that. when reduced gradually

* Dr. J. G. Hunt (Am. Nat. 9:575. I875) states that the coloring matter of "red snow" leaves unchanged the red, orange and yellow portions of the spectrum but entirely absorbs the violet portion. It may be assumed, then, that the coloringmatter of Sphaerella nivalis is identical with the haematochrom of S. lacustris. 
from a temperature of $\mathrm{I} 8^{\circ}$ even to the point where the surface of the water became coated with ice the zooids all the time sought the lighter side of the glass dish. Some of the variations in experiments with zooids may be due to currents in the water, for Sachs (' 76 ) was able to produce many of the phenomena exhibited by zoöspores by means of minute oil globules.

Microzooids are usually more positively attracted to light than megazooids, so that in cultures where both are present, as Sachs (' 76 ) has noted, the microzooids are sometimes found only on the more illuminated margin while most of the megazooids accumulate on the other side. I have found that, when taken from the light of a north window and placed in bright sunlight at a south window, megazooids will at first be neutral or even shun the light, but later will recover from the shock and swim toward the more intense light ; red zooids recover most quickly and young green ones more quickly than older ones of the same color. The microzooids, on the other hand, from the very first swim toward the increased light, and when the slide is turned around they instantly turn and swim to the newly illuminated side. If, while they are moving from one side to the other, the sunlight is cut off they will go to all parts of the drop, but when the sunlight is again admitted they will immediately swim toward it.

Zooids transferred from the light of a north window to bright sunlight will not live for more than an hour, and the microzooids usually not so long as that, though they thrive when cultivated in sunlight from the first or when the change is gradual.

\section{Conditions affecting Vitality}

The difficulty of obtaining a long cycle of development in drop cultures, owing probably to insufficient aëration, has prevented the determination of the number of generations that may be produced in a cycle. There is every reason to believe, however, as Braun and Cohn supposed, that a considerable number of successive motile generations may be formed in a colony. The colony may remain in the motile state for a few days or even for three or four weeks. The length of this period depends in some measure, at least, upon the food supply. My best results have been obtained in cultures containing decaying vegetable matter; somewhat less 
successful has been the use of Sachs' food solution. Good light and aëration also encourage longer movement. It has been thought (Cohn '50) that zooids kept in the dark would not produce secondary generations, and very generally I have found this to be the case ; such a condition might easily be accounted for by the fact that the darkness does not allow a growth vigorous enough to promote this asexual division. Zcoids kept in darkened cultures generally remain small, and after some days it will be found that they are narrower and more attenuated anteriorly than those kept under normal conditions (Fig. 36). That secondary division is not impossible, however, in cultures to which light has not been admitted, is proved by the fact that I have sometimes found cells producing zooids of the second or third generation after two days in such cultures (Fig. 3 I). After the zooids have finally come to rest and acquired a thick, permanent cell-wall no further division will take place until after some change in the environment. Alexander Braun (' 5 I) stated that desiccation must intervene; otherwise the cells would become blanched and lifeless. Often my cultures have confirmed this opinion, but during the present winter I have repeatedly found that freezing will meet the requirement just as well ; in fact, propagation has been more vigorous after freezing than after drying, possibly because desiccation is sometimes too rapid in a warm room.

Dangeard ('88) says that he kept resting cells in the bottom of a vase for a year without desiccation and then, when they were transferred to damp cells, division occurred. Nevertheless it is not impossible that freezing or a new food supply brought about the required change in this case.

Relation of Sphaerella nivalis to S. Lacustris

Rabenhorst ('68) expressed a doubt as to the distinctness of these two species. Rostafinski ('75) after studying for four years the development of the species then called Chlamydococcus pluitalis, but without having seen $C$. nir alis, united the latter with the former under the name Hacmatococcus lacustris (Girod) Rostaf. The grounds for making this union were (I) The similarity of the development of the two species as shown by the comparison of some (apparently unpublished) drawings of C. mivalis by Schimper 
with what Rostafinski knew in regard to C. plusialis; (2) The fact (?)* that he was able to cultivate Chlamydococcus pluirialis in snow and to produce zoöspores at a low temperature.

Now in making this physiological point, which remains unconfirmed, a ground of identity, more important points of difference of a similar nature have been left out of account. There is no record to show that Sphacrella nivalis may be cultivated at an ordinary temperature; on the contrary, Chodat ('96) was unable to cultivate a red snow alga (which he supposed to be $S$. mizalis) except at a very low temperature. Furthermore, Cohn ('54) was unable to produce any development from " red snow" material either when preserved in snow water or dried, while Braun (' 5 I) records that motile cells were obtained from material of Sphacrella lucustris after it had been preserved seven years in a herbarium.

I have myself attempted without success to cultivate in snow some of the "red snow" cells which have preserved their color and normal appearance in spite of being kept in the melted snow for over two years.

The only important morphological difference seems to be that no protoplasmic threads connecting the central mass with the cellwall have been observed in Sphacrella nivalis. This, together with the physiological difference mentioned above, has seemed to Chodat ('96) sufficient ground for maintaining even the generic distinctness of the two species, and he, therefore, retains the name Hacmatococcus lacustris to separate this species from Splacella niialis. It appears to me, however, that no more than a specific distinctness between the two forms can be maintained.

\section{Nomexclature}

The nomenclature of Sphacrella is in such a confused state that it has given rise to some serious errors in regard to the life history. A brief historical sketch may therefore be found desirable.

In I 828 Agardht established the genus Hacmatococcus and transferred to it the species he had previously called Protococcus nivalis. When Flotow published his memoir in I 844 , not being

* See section on vegetative division.

†C. A. Agardh. Icon. Alg. Eur. Nos. 21-23, IS 2S.

+ Syst. $\mathrm{I}^{\prime} \mathrm{g} \cdot \mathrm{I}_{3} . \mathrm{I} \mathrm{S}_{24}$. 
able to identify his plant with any described earlier, he called it Hacmatococcus pluiralis.

Kützing ('45) rejected the genus Haematococcus and placed the species of Flotow under Agardh's first genus Protococcus, and this name was adopted by Cohn ('53).

Alexander Braun (' 5 I ), considering our species generically distinct from Haemalococcus (Protococcus) nizalis, founded for it a new genus and gave it the name Chlamydococcus pluiralis.

In I 875 Rostafinski decided that this species was generically and even specifically identical with the "red snow" species and therefore restored it to the genus Hacmatococcus; he further identified it with the Voliox lacustris described by Girod-Chantrans in I 802 , and made the new combination Hasmatococcus lacustris. Perty ('52) had anticipated Rostafinski in recognizing Girod's Voliox lacustris as the commonly known species, but he regarded it as an animal when in the motile condition and gave it the name Hysgimum pluviale, placing it in his class Phytozooidia.

In $188_{3}$ Wittrock* revived for the "red snow" species the name Sphaerella nivalis Sommerf. which, though four years older than Haematococcus micalis Ag., had never come into general use. In I 886 Wittrock changed our rainwater species which he had previously called Haematococcus lacustrist to Sphaerclla pluvialis.+

It is not clear why he did not keep the specific name lacustris : it may be that he was influenced by the fact that Cohn ('S I, '82) had refused to accept it, mainly on the ground that Girod's Volrox lacustris was found in salt water while the common species is now known only in fresh water. Finally, however, Wittrock $\$$ returned to the first specific name with the combination Sphacrella lacustris (Girod) Wittr.

Objection to the revival of Sommerfelt's generic name Splacerella was made by Berlese and De Toni ('87) on the ground (1) That the genus was poorly defined, and (2) That it would cause

* V. B. Wittrock. O.n snöns och isens flora särskildt i artiska trakterna. Stockholm. I 883 .

† Wittrock and Nordstedt. A'g. Exsic. No. 156.1878 .

Ibid. No. 733 . I 886 .

8. A. Hansgirg. Prodromus der Algen F ora von Böhmen. Arch. d. Nat. Land. v. Böhm. 66 : 105. I 888 . 
a great increase of synonyms if this revival were to hold, for it would necessitate the change of name of the large number of species of the fungus genus Sphacrella established by Cesati and De Notaris in 1863 .

As for the first objection, in spite of the fact that the original characterization of Sommerfelt's genus is brief and under it is included a species now known to belong to another genus (Palmalia botryoides (L.yngb.) Kütz.), nevertheless the well-known species Sphacrella mivalis is placed first and the genus was evidently founded on it. The second objection has no weight, certainly at the present time, for most of the species of the genus of Cesati and De Notaris have now been transferred* to Mycosphacrella, a genus established in I 885 by Johanson $\dagger$ to take the place of the genus of Cesati and De Notaris.

It is clear, then, that the name Hacmatococcus established by Agardh in I 828 must give way to Splacerella established by Sommerfelt ('24) four years earlier.

In the following list I have omitted Hacmatococcus mucosus Morr., first identified with our species by Rabenhorst ('68) because I cannot recognize in Morren's description or figures any sufficient resemblance to Sphacrella. I have added Disceraca purpurea Morr. which, though it is identical with our species and was so regarded by Cohn (' 50 ) and Perty (' 52 ), has been omitted from other lists of synonyms, probably because Morren considered his organism an animal.

It may be remarked that among modern zoölogists Stein and Bütschli have included our alga, together with the rest of the Vo:vocaceae, in the Protozoa, but Saville-Kent and most authors of biological text-books have-with more justice as it appears to us -relegated it to the plant realm.

\section{SiTONOMY}

Volvox lacustris Girod. Rech. chim. et mic. 54, iS6. I So2.

Protococius monospermus Corda; Sturm's Deutschland's Flora $2^{25}$ : 1 $829-32$.

Disceraea purpurea Morren. Rech. phys. sur les Hydroph. d. Belg. 3 : $37-43 ; 4: 42-45$. Nouv. Nem. Acad. Roy. Sci. Brux. I4: I $S_{4}$ I.

* See Engler and Prant1. Die nat. P'flanzenfam. I1: 423-426. IS97.

† Öfvers. af K. Svensk. Vet. Akad. F örhand. $4 \mathbf{I}^{9}: \mathbf{1} 6_{3}, \mathbf{I} 6_{4}$. ISS 5 . 
Haematococcus Cordae Meneghini. Mem. R. Accad. Sci. di Tor. II. 5: $20 . \quad 1843$.

Haematococcus pluvialis Flotow. Nov. Act. Acad. Caes. 20²: 4I $3-$ 606. I 844. Sachs ('76, '87), Cohn ('81, '82), Bütschli ('84), Parker ('93), Zopf ('95).

Protococcus pluvialıs Kützing. Phyc. Germ. I 46. I 845. Tab. Phyc. I : 2. I 849. Cohn ('50), White ('80), Gibson ('89), Bennett and Murray ('89), Huxley and Martin ('92).

Protosphaeria pluvialis Trevisan. Atti Congr. Sci. Ital. in Ven. 28. I 848 .

Protosphaeria Cordae Trevisan. Atti Congr. Sci. Ital. in Ven. 28. $18+8$.

Chlamydococcus pluvialis Al. Braun. Betracht. über die Erschein. d. Verjüng. in d. Nat. 219. I 85 I. Cohn ('52, '54, '67), Pritchard ('6r), Rabenhorst ('68), Velten ('7 I), Rostafinski ('7 I), Stein ('78), Kirchner, Krypt.-Flor. Schles. I878. Wolle, Fresh-Water Alg. U. S. I64. I887. Cooke, Brit. Fresh-Water Alg. 5 I. I882. Demetzky ('83), De Toni and Levi, Flor. Alg. Ven. i888. Dangeard ('88).

Hysginum pluviale Perty. Zur Kentn. kleinst. Lebensf. 87-95. I852. Hacmatococcus lacustris (Girod) Rostafinski. Mem. Soc. Nat. Sci.

Nat. Cherb. II. 9: I 40. I875. De Toni ('89), Chodat ('96, '97), Phyc. Bor. Am. No. I I 4. I 895. Bütschli ('84, Pl. 43).

Sphaerella pluvialis (Flot.) Wittrock. Wittr. and Nordst. Alg. Exsic.

No. 733. I886. Wille; Engler and Prantl, Die nat. Pflanz. I²:

39. 1897.

Sphaerella lacustris (Girod) Wittrock. Arch. d. Nat. Land. v. Böhm. $6^{6}: 105 . \quad 1888$.

\section{SUMNARY \\ A. Life History}

I. The ordinary Cycle of Development

I. The normal resting-cell forms by endogenous division four, eight, or sixteen daughter-cells.

2a. Under unfavorable conditions these daughter-cells remain in the resting condition and return to stage $I$.

2b. Under favorable conditions these daughter-cells escape from the mother-cell-wall as free-swimming megazooids, which may while motile grow to four times their original size. 
3a. These megazooids may return immediately to the resting condition I, by secreting a new thick cell-wall inside the distended wall which they possess as zooids, or

3b. The megazooids may come to rest temporarily, not forming any thick cell-wall.

$4 a$. These temporarily resting zooids may divide into two or four new megazooids which repeat the development of $2 b$, indefinitely, or

4b. They may form eight, sixteen, thirty-two, or sixty-four (?) microzooids which swarm actively inside the mother-cell-wall and finally break out.

5 a. These microzooids frequently die.

5b. Sometimes they come to rest, form a cell-wall and increase to the size of ordinary resting-cells.

\section{The Cycle of Microzooids}

Certain resting-cells (probably poorly nourished) form instead of megazooids, eight, sixteen, thirty-two, or sixty-four (?) microzooids which die or conjugate (?) or grow into the ordinary restingcells.

\section{B. General Conclusions}

I. There are two forms of motile cells produced by Sphacrella lacustris : megazooids and microzooids.

2. The megazooids are asexual.

3. No conjugation of microzooids has been observed, but from the conditions of their formation we should expect to find such a process.

4. The vegetative division does not differ in manner from the formation of megazooids; unfavorable conditions prevent the assumption of the motile state.

5. Sphacrella lacustris does not pass into an amoeboid form.

6. The cell-wall both in motile and resting conditions consists of cellulose.

7. Several pyrenoids about which starch is deposited are embedded in the chromatophore.

8. No contractile vacuole is present.

9. Haematochrom is a substance closely allied to chlorophyl 
but more stable; its value probably lies in this stability and perhaps also in its protective and heat-producing power.

IO. The zooids are generally strongly attracted toward the light.

I I. Some interruption of development surch as desiccation or freezing is necessary for preservation of vitality.

I 2. Sphaerella lacustris is to be regarded as a plant because of the possession of a cellulose cell-wall and chlorophyl and the holophytic mode of nutrition.

I 3. The "red snow" species Sphacrella nicalis is regarded as distinct from $S$. lacustris on the grounds of morphological and physiological differences.

\section{LITERATURE}

In the following list the important papers relating to the life history and nomenclature of Sphaerclla lacustris are collected. It has been intended also to note all original illustrations.

The memoir of Braun (' $5 \mathrm{I}$ ) gives by far the clearest and most accurate account of the life history, but it has been little used by later writers. The work of Cohn (' 50 ) which has been chiefly drawn upon for brief accounts, though of great value, is nevertheless not so clear, and has been misrepresented in translations and abstracts. There are several minor accounts in text-books, which, possessing no merit of originality and in some cases the positive demerit of inaccuracy, have not been included in this list.

Bennett, A. W. \& Murray, G. Handbook of Cryptogamic Botany, 4I5, 4I6. London, I889.

Berlese, A. N. \& De Toni, G. B. Intorno al genere Sphaerella di

Cesati e De Notaris ed all' Omonimo di Sommerfelt. Atti Reale Ist. Ven. d. Sci. VI. $5^{1}$ : 22 I-228. 1887.

Braun, Al. Betractungen über die Ersheinung der Verjüngung in der Natur. Leipzig, I 85 I. (Translation by A. Henfrey, Bot. and Phys. Mem. Ray Soc. 1853.) (Abstract in Cooke, M. C. Brit. Fresh-Water Algae 51-54. I882.)

Braun, Al. Chlamydococcus pluílalis bei Berlin. Bot. Zeit. Io: 245-247. 1852 .

Bütschli, O. Protozoa, $2: 836$. Leipzig, r 884 .

Busk, G. Abstract of Cohn's Natural History of Protococcus dluvialis.

Bot. and Phys. Mem. Ray Soc. 1853.

Chodat, R. Sur la flore des neiges du Col des Écandies. Bull. Herb.

Boiss. 4: $880-889$. 1896 . 
Chodat, R. Études de biologie lacustre. Bull. Herb. Boiss. 5 : 291, 292. I $897 ; 6: 40-77.1898$.

Сонn, F. Nachträge zur Naturgeschichte des Protococcus pluvialis Kützing. Nov. Act. Acad. Caes 222 : 605-764. pl. 67, A. B. I850. (W. B. Carpenter, The Microscope and its Revelations, 473-477. London, I 891.)

Cohs, F. Ueber eine neue Gattung aus der Familie der Volvocinen. Zeitschr. f. Wissen. Zool. 4: 77-II6. I 852. (Transl. by A. Henfrey, Ann. and Mag. Nat. Hist. II. Io: $32 \mathrm{I}-347$. I852.)

Сонк, F. Untersuchungen über die Entwicklungsgeschichte der mikroskopischen Algen und Pilze. Nov. Act. Acad. Caes 24: ror256. pl. $18 . f .1-8$. 1854 .

Cons, F. Beiträge zur Physiologie der Phychromaceen und Florideen. Arch. f. mik. Anat. 3:44, 45. I 867 .

Сонn, F. Ueber Hacmatococcus pluvialis. Jahresber. d. Schles. Ges. f. vaterl. Cult. I88 I. (Bot. Jahresber. I88I : 368 . I 884.)

Conn, F. Ueber blutrothe Algen und Pilze. Jahresber. d. Schles. Ges. f. vaterl. Cult. 1882: 207. I882. (Bot. Jahresber. 1882: 323. I 884.)

Corda, A. C. J. Die Algen in Sturm's Deutschland's Flora. $2^{25}:-$ $x 829-32$.

Dangeard, P. A. Recherches sur les Algues inférieures. Ann. Sci. Nat. Bot. VII. 7 : I 38 -I 4 I. pl. I2.f. $41-47$. I 888.

Denetzky, J. A. Véres esöröl. (Vom Blutregen.) Természet. Közlön. I5 : 24I-25I. pl. I883. (Bot. Jahresber. I883 : $28 \mathrm{I}$. I885.)

De Toni, J. B. Sylloge Algarum, I : 55I-553. Patavii, I 889.

Engelmann, T. W. Ueber Assimilation von Hacmatococcus. Bot. Zeit. 40: $66_{3}-679$. 1882 .

Flotow, J. von. Ueber Haematococcus pluvialis. Nov. Act. Acad. Caes. 20²: 41 3-606. pl. 24, 25. I 844 .

Gibson, R. J. H. Textbook of Elementary Biology, 69-7x. London, I889. (Fig. I 7, which was copied from Howe's Atlas of Practical Elementary Biology, does not represent Protococcus pluvialis.)

Girod-Chantrans, J. Recherches chimiques et microscopiques sur les Conferves, Bysses, Tremelles, etc., 54, I86. pl. 8. f. I7. Paris, 1802 .

Hansgirg, A. Prodromus der Algenflora von Böhmen. Arch. d. Nat. Land. v. Böhm. 66: 105, 106. 1888.

Herrick, F. H. On Hacmatococcus. Science 9: 319, 320. I\$99. (Abstract of a paper read before the American Morphological Society, Dec., 1898.$)$ 
Huxley, T. H. \& Martin, H. N. Practical Biology, 389-395. London, 1892 .

KütZing, F. T. Phycologia Germanica, I46. Nordhausen, I845. KÜtzing, F. T. Tabulae Phycologiae, I : 2. Nordhausen, I 849 . Meneghini, G. Monographia Nostochinearum Italicarum. Mem. Reale Accad. Sci. di Torino. II. 5 : 20. pl. I. f. 5. 1843.

Morren, A. \& C. Recherches physiologiques sur les Hydrophytes de Belgique, 3: 37-43; $4: 42-45$. pl. 3. f. I-I2. Nouv.

Mem. Acad. Roy. Sci. Brux. r4: I84I.

Parker, T. J. Elementary Biology, 23-35. f.3. $A-D$. London, I893. Perty, M. Zur Kentniss kleinster Lebensformen, 87-95. pl. I2. f. 2. Bern, $185^{2}$.

Pritchard, A. History of Infusoria, I48-I 52, 523-524. London, I86I. Rabenhorst, L. Flora Europaea Algarum, 3 : 93, 94. Lipsiae, r 868. Rostafinski, J. Beobachtungen ïber Paarung von Schwärmsporen.

Bot. Zeit. $29: 788-790 . \quad$ I 87 I.

Rostafinski, J. Quelques mots sur l'Haematococcus lacustris et la classification des Chlorosporées. Mem. Soc. Nat. Sci. Nat. Cherb. II. 9 : $137-154 . \quad$ I 875 .

Rostafinski, J. Ueber den rothen Farbstoff einiger Chlorophyceen, etc. Bot. Zeit. $39: 46 \mathrm{I}-465$. I88I.

SACHS, J. Ueber Emulsionsfiguren und Gruppirung der Schwärmsporen im Wasser. Flora 59: 273-275. I 876. (Physiology of Plants, 609, 61о. I887.)

Sommerfelt, S. C. Om den röde Snee, eller Sphaerella nivalis Sommerf., Uredo nivalis Auct. Mag. for Naturvid. 4: 249-253. I 824.

Stein, F. Der Organismus der Infusionsthiere. 3: I4-2 I, 52-69. pl. $15 \cdot f \cdot 51-54 \cdot p l .24 \cdot f \cdot 26-46$. Leipzig, 1878 .

Strasburger, E. Wirkung des Lichtes und der Wärme auf Schwärmsporen. Jena, 1878. (Vines, Physiology of Plants, 524-526. I886.) (Sachs, Physiology of Plants, 6I I, 6I 2. I887.)

Trevisan di S., L. V. Saggio di una Monographia delle Alghe coccotalle. Atti Congr. Sci. Ital. in Ven. 28. Padova, 1848.

Velten, W. Beobachtungen über Paarung von Schwärmsporen. Bot. Zeit. $29: 383-388$. pl. 5 A.f. I-9. 187 I.

White, T. C. On the Resting Spores of Protococcus pluvialis. Jour. Quekett Mic. Club, 6: 43-46. I 880 .

Wittrock \& Nordstedt. Algae Exsiccatae. No. I56. I878; No. 733. 1886.

Zopf, W. Cohn's Haematochrom ein Sammelbegriff. Biol. Centralb.

I5: 4I7-427. I895.

Columbia University, April, I899. 


\section{Hazen : Life History of Sphaerella lacustris}

\section{INDEX}

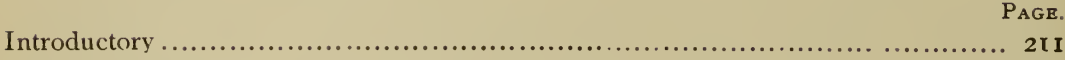

General account.......................................................... 21 2

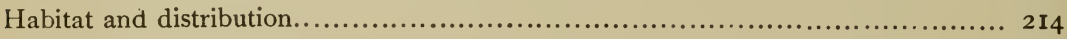

The resting condition..................................................... 216

Reproduction............................................................. 2 I 7

The formation of megazooids........................................ 217

The first generation............................................ 2 I 7

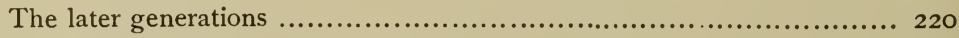

Vegetative division...................................................... 220

The formation of microzooids......................................... 223

The so-called conjugation of megazooids...................................... 225

The alleged amoeboid condition. ........................................... 226

Special morphology of megazoids............................................. 226

The cell-wall and sheaths of cilia....................................... 226

The radial strands of protoplasm...................................... 227

The chromatophore and pyrenoids...................................... 227

A contractile vacuole not present........................................ 229

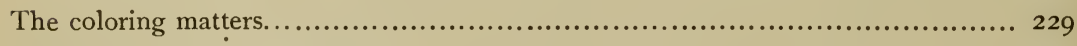

Function of the haematochrom.

Irritability of zooids. ..................................................... 233

Conditions affecting vitality. .............................................. 234

Relation to Sphaerella nivalis to $S$. lacustris................................. 235

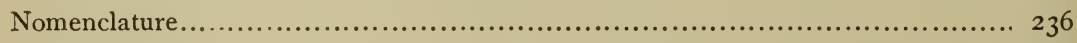

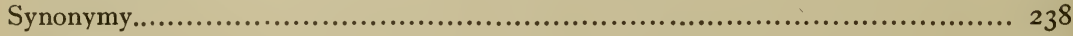

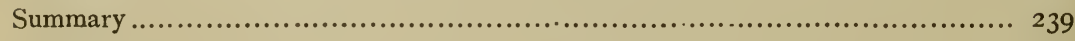

Literature................................................................ 24 I

Description of plates........................................................ 245 

mem. Torr. Bot. Cleub.
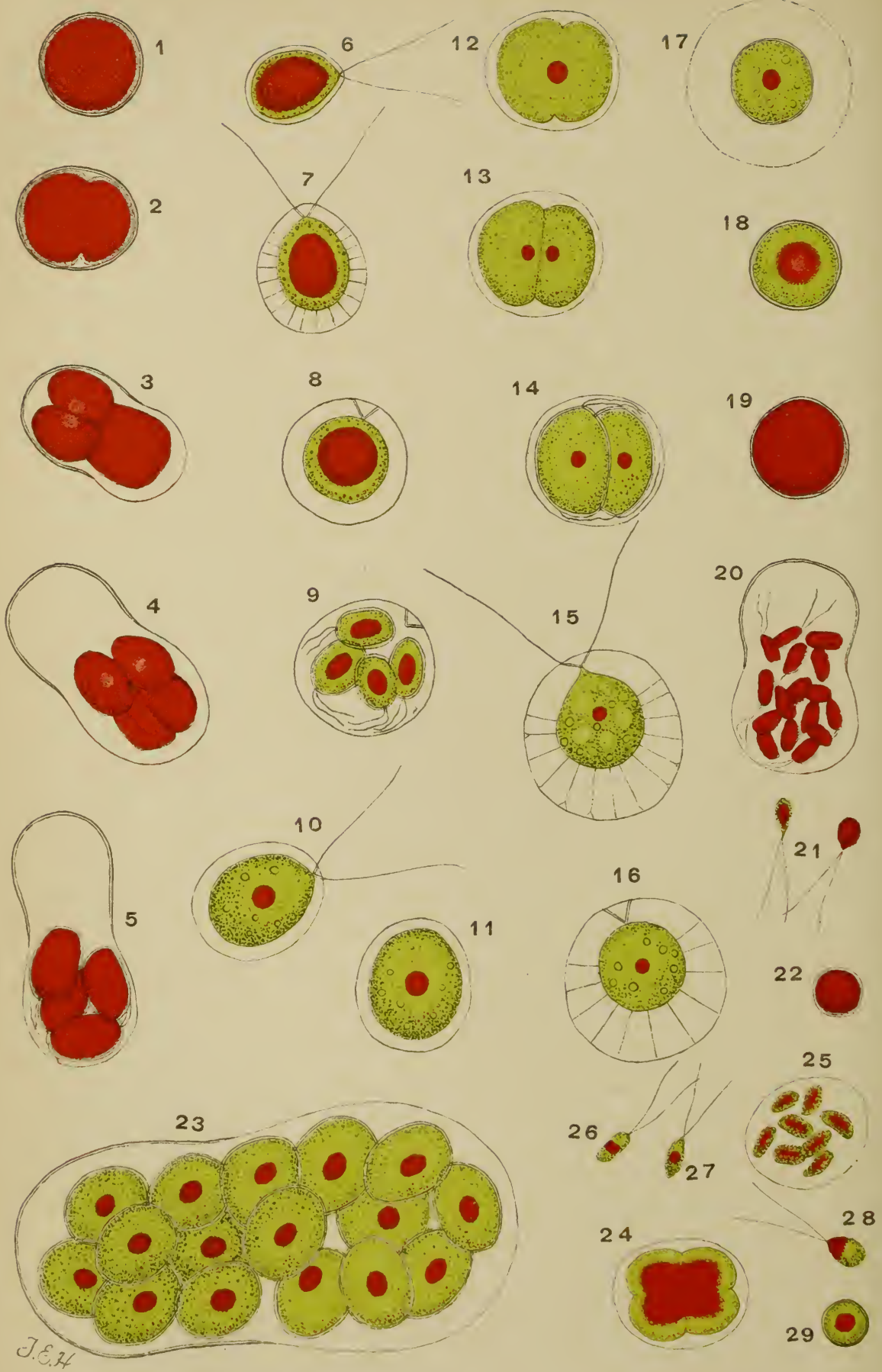

SPHAERELLA LACLSTRIS (Girod.) Wittrock. 


\section{Explanation of Plate 86}

Figures I-I 9 have been placed in a series so as to illustrate the ordinary cycle of development. Figures $\mathbf{1 9 - 2 2}$ represent the cycle of the microzooids as far as it has been observed.

FIG. I. A typical resting cell.

FIG. 2. The beginning of division. 8:00 a. m.

FIG. 3. The transverse division completed, longitudinal division completed in one hemisphere ; the outer layer of the cell-wall has ruptured and the thin inner layer is pushed out. 8:30 a. m.

FIG. 4. Division nearly completed. 9:00 a. m.

FIG. 5. The daughter-cells are clothed with delicate cell-walls and their cilia are seen just before they break out. 9:15 a. $\mathrm{m}$.

FIG. 6. One of the megazooids after swimming freely for an hour or two, has acquired a narrow yellowish-green border of chlorophyl.

FIG. 7. A megazooid several hours older, showing the radial protoplasmic threads and widely distended cell-wall.

FIG. 8. A quiescent megazooid whose protoplasmic processes have disappeared in preparation for division; the sheaths which invested the bases of the cilia remain.

FIG. 9. Four megazooids produced on the second morning. 9:15 a. m.

FIG. IO. A megazooid of the second generation which has developed considerable chlorophyl and prominent pyrenoids.

FIG. II. The same become quiescent for division.

FIG. I2. Beginning of division to form the third (or a later ?) generation. 8:30 a. m.

FIG. 13. Continuation of division. 8:45.

FIG. I4. The daughter-cells completely formed turn inside the mother cell-wall. II:30. No further growth was perceptible befure 2:15 p. m. when the megazooids escaped.

FIG. 15. A mature megazooid showing a vacuolated chromatophore, and finely branched protoplasmic threads.

FIG. I6. The same become quiescent.

FIG. 17. The thick, permanent cell-wall formed; the distended wall of the zooid disintegrating.

FIG. I8. Increase of haematochrom as resting condition advances.

FIG. 19. The resting-cell ; the cycle of development closed.

Fig. 20. After desiccation or freezing the resting-cell of Fig. I9 forms sixteen micro. zooids.

FIG. 21. Microzooids.

FIG. 22. A microzooid come to the resting condition.

FIG. 23. A cell taken from resting vegetation (frozen) producing sixteen large megazooids in the laboratory. [Dec. 2, New York.]

FIG. 24. A first-generation megazooid beginning to divide. 9:30 a. m.

FIG. 25. Continuation : eight microzooids swarming. 10:30.

Figs. 26, 27, 28. Different forms of microzooids.

FIG. 29. One of these microzooids going into the resting state. 


\section{Explanation of Plate 87}

FIG. 30. Optical section of a mature megazooid of average size. [Baltimore.]

FIG. 31. Two zooids produced in a megazooid kept in the dark two days. [Burlington.]

FIG. 32. Megazooids devoid of haematochrom, from a colony two weeks old. [Baltimore.]

FIG. 33. Production of a secondary generation where the haematochrom has all gone - into one daughter-cell, uncommon. [Burlington.]

FIG. 34. So small a slit is made that the zooid is compressed in squeezing out, but

FIG. 35. It soon resumes the usual form.

FIG. 36. A zooid developed in darkness three days. [Burlington.]

FIG. 37. A late generation in which the lifeless cilia of the mother-cell remain during division. [Baltimore.]

FIG. 38. The mother-cilia, still active, are attached to one of the daughter-zooids, both of which move independently. [Baltimore.]

FIG. 39, A megazooid ciliated at each end. [New York.]

FIG. 40. A pair of megazooids incompletely separated. [Burlington.]

FIG. 4I. A similar monstrosity with three heads [Burlington.]

FIGS. 42-44. Fusion of a pair of incompletely formed megazuoids. [Burlington.]

FIG. 45. A cell from resting vegetation in open air. [Feb. I, New York.]

FIG. 46. The same cell commencing division the next morning. 9:00 a. m.

FIG. 47. Continuation of division. 9: ro.

FIG. 48. Later stage. 9:30. No further growth except that the formation of cellwalls was visible when the magazooids escaped at $10: 30$.

FIG. 49. Eight daughter-cells of the first generation; prevented from becoming motile apparently by cold. [Burlington.]

FIG. 50. An extremely large megazooid (48 $\mu$ long) with a solid chromatophore. [New York.]

FIG. 5I. A very small mature megazooid, Io $u$ long. [Ithaca.]

FIG. 52. Four megazooids of the second generation from a zooid which had remained red twenty-four hours. [Burlington.]

Note. All the figures are magnified about 630 times ; in all cases the living plants were carefully measured by means of an eyepiece micrometer and drawn to scale as though projected by a camera lucida. The colors represent the average, but do not $\mathrm{n}$ dicate the great variety of tints shown in the living plants under different conditions. In most cases the source of the material from which each figure was drawn is appended to its description. 


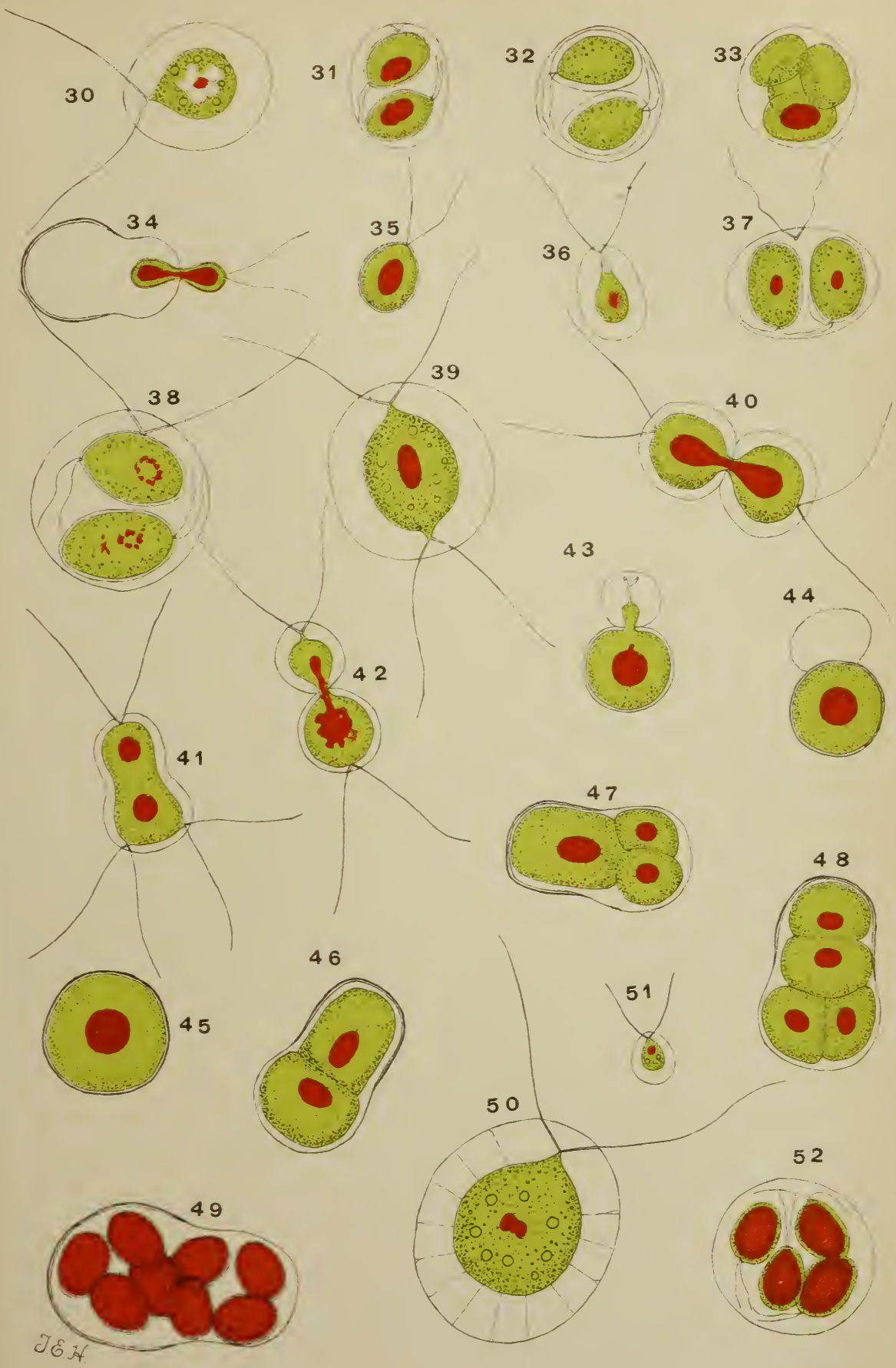

SPHAERELLA LACUSTRIS (Girod.) Wittrock. 



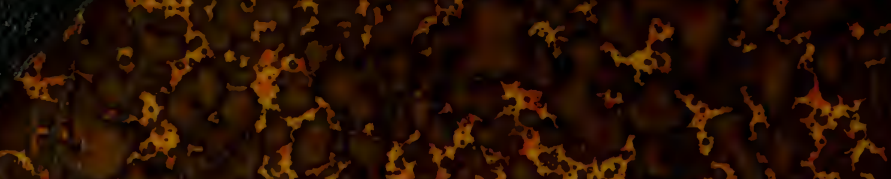

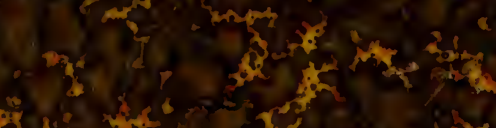

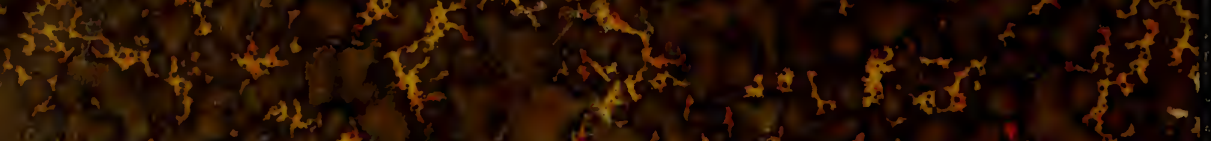

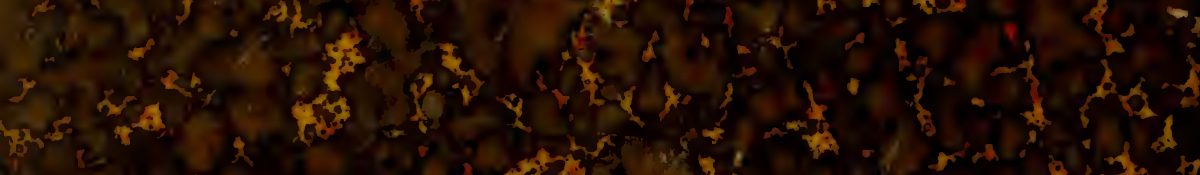
(2) a

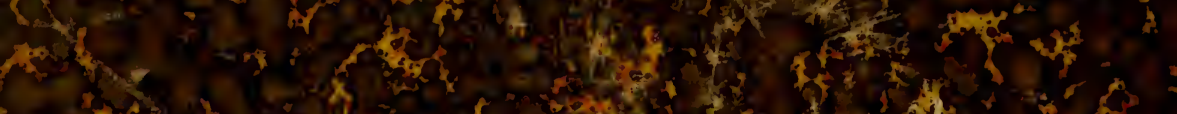

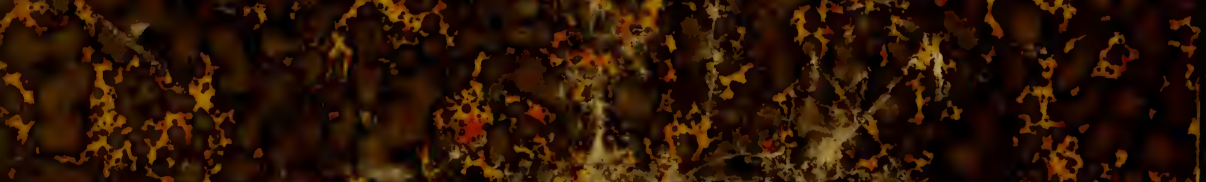

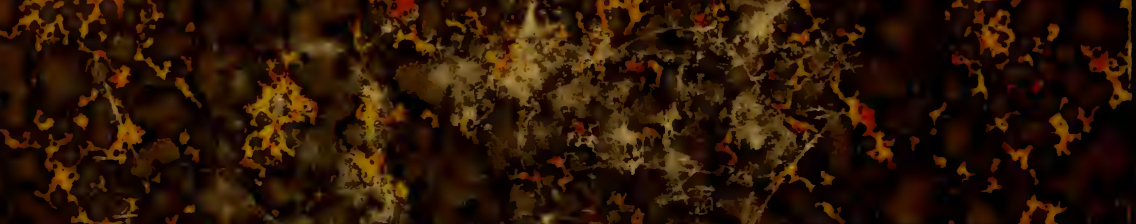

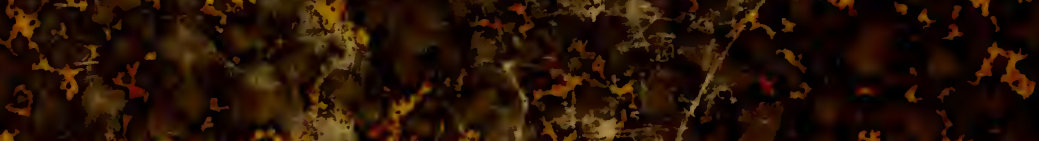

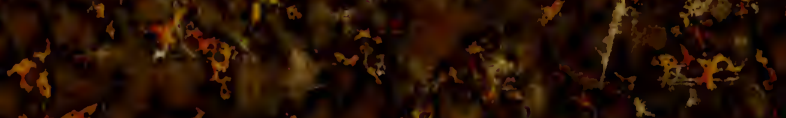
ryoteris$$
\text { है। }
$$

$$
x^{n}
$$

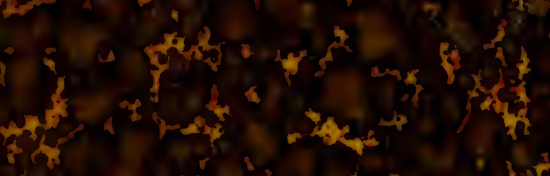

s)

13.5.

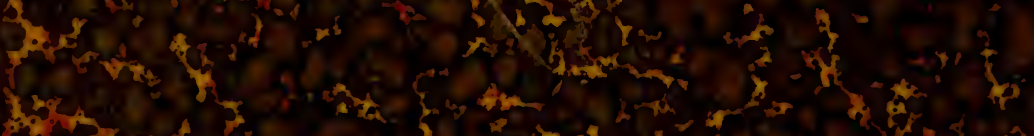

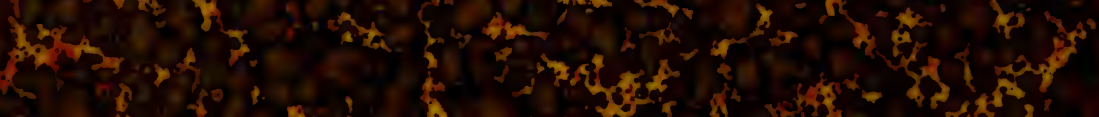

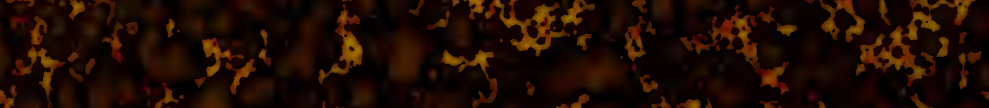

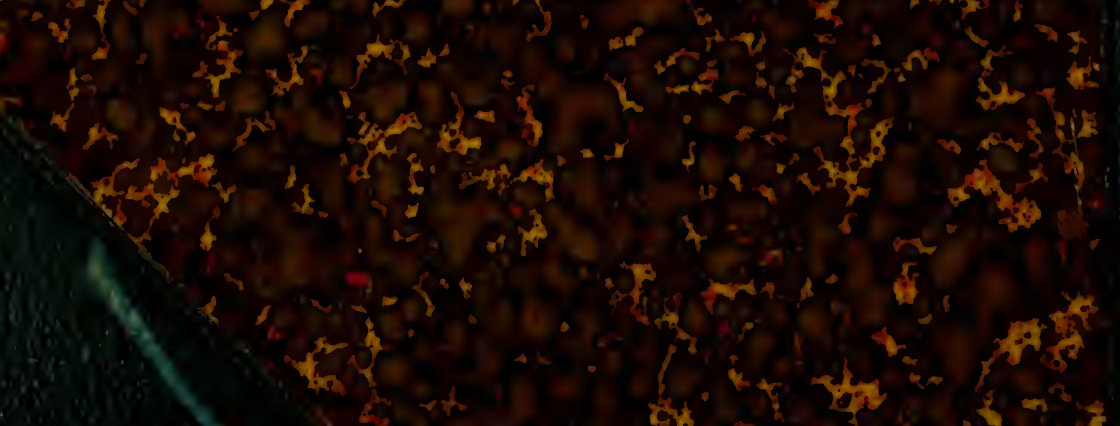

